\title{
РОЗРОБКА МЕТОДИК КОНТРОЛЮ ЯКОСТІ ПРЕПАРАТУ ЛЕСФАЛЬ РОЗЧИН ДЛЯ ІН'ЄКЦІЙ
}

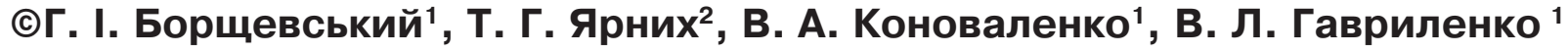 \\ 1 ПАТ «Фармак», Київ \\ ${ }^{2}$ Національний фармацевтичний університет, Харків
}

Резюме: розроблено методики контролю якості ліпосомального ін'єкційного розчину Лесфаль. Запропонований аналітичний метод визначення вмісту фосфатидилхоліну, специфічний, лінійній, точний і правильний в діапазоні концентрацій діючої речовини 76-126 \%. Межа виявлення лізофосфатидилхоліну складає 0,01167 мг/мл, межа кількісного визначення складає 0,03534 мг/мл.

Ключові слова: розчин для ін'єкцій, розробка, методики контролю якості.

Вступ. Створення лікарського препарату включає ряд послідовних етапів експериментальних наукових досліджень. Одним із таких $€$ розробка методик контролю якості, які є безпосереднім критерієм вибору раціональної технології та оцінки стабільності лікарської форми [6, 7].

Для лікування захворювань печінки запропоновано вітчизняний ліпосомальний ін'єкційний розчин Лесфаль на основі ессенціальних фосфоліпідів [3].

Як діючу речовину препарату Лесфаль використано фосфатидилхолін з соєвих бобів висушеної субстанції, що містить 93 \% (3-sn-фосфатидил) холіну (ессенціальні фосфоліпіди). До складу основних допоміжних речовин входять спирт бензиловий та дезоксихолієва кислота [1, 4].

Методики контролю якості препарату розроблено відповідно до провідних фармакопей світу та Державної фармакопеї України (ДФУ) $[2,5]$. Специфікація методик контролю якості включає такі розділи, як опис, ідентифікація, прозорість, кольоровість, механічні включення (видимі та невидимі частки), відносна густина, $\mathrm{pH}$, стерильність, бактеріальні ендотоксини, кількісний вміст фосфатидилхоліну, лізофосфатидилхоліну та бензилового спирту.

Особливої уваги у фармацевтичній розробці даного лікарського засобу заслуговує розробка методик кількісного визначення фосфатидилхоліну та лізофосфатидилхоліну.

Метою даної роботи є розробка та валідація методик кількісного визначення фосфатидилхоліну та лізофосфатидилхоліну в препараті Лесфаль розчин для ін'єкцій.

Методи дослідження. При розробці методики кількісного визначення використовували обладнання: хроматограф рідинний «Agilent» 3 DAD - детектором, Shimadzu з УФ-детектором, ваги Sartorius ED 412S № 19007364.
Для кількісного визначення фосфатидилхоліну та лізофосфатидилхоліну використовували колонку сталеву розміром 250×4,6 мм, заповнену сорбентом Kromasil Si з розміром часток 5 мкм або аналогічна, яка витримувала вимоги придатності хроматографічної системи.

Як рухому фазу використовували суміш ізопропанол - н-гексан - вода $P(67: 16,5: 16)$, яка дегазувалася за допомогою ультразвуку. Швидкість рухомої фази становила 1,0 мл/хв; детектування проводили при довжині хвилі 205 нм; температура колонки складала $40{ }^{\circ} \mathrm{C}$; об'єм інжекції становив 50 мкл.

Як стандартні зразки використовували фосфатидилхолін («Sigma», кат. № P7443), L- $\alpha$ Lysophosphatidylcholine c.010M5203 Sigma, бензиловий спирт («R-de-H» 24122).

Результати й обговорення. Для кількісного визначення фосфатидилхоліну аліквотну частину препарату переносили в мірну колбу, доводили метанолом до позначки, фільтрували крізь фільтр PVDF з розміром пор не більше 0,45 мкм. Розчин порівняння - фосфатидилхолін (кат. «Sigma», кат. № L 0906).

Хроматографічну систему вважали придатною, якщо: кількість теоретичних тарілок, розрахована за піком фосфатидилхоліну, становила не менше 2000; відносне стандартне відхилення, розраховане для 5 площ піку фосфатидилхоліну на хроматограмі розчину порівняння, не перевищувала 2,0 \%; коефіцієнт розділення між піками фосфатидилхоліну та лізофосфатидилхоліну мав бути не менше 4,0.

Вміст фосфатидилхоліну в 1 мл препарату $\left(\mathrm{X}_{3}\right)$, в міліграмах, розраховували за формулою:

$$
X_{3}=\frac{S_{1} \cdot m_{0} \cdot 50 \cdot P \cdot \rho}{S_{0} \cdot 100 \cdot m_{1} \cdot 100}=\frac{S_{1} \cdot m_{0} \cdot P \cdot \rho}{S_{0} \cdot m_{1} \cdot 200},
$$

ISSN 2312-0967. Pharmaceutical review. 2015. № 1 
Аналіз лікарських препаратів

Analysis of drugs

де $\mathrm{S}_{0}$ - середнє значення площі піку фосфатидилхоліну на хроматограмі розчину порівняння;

$\mathrm{S}_{1}$ - середнє значення площі піку фосфатидилхоліну на хроматограмі випробовуваного розчину;

$\mathrm{m}_{0}$ - наважка фосфатидилхоліну, використаного для приготування розчину порівняння, у міліграмах;

$\mathrm{m}_{1}$ - наважка препарату, використаного для приготування випробовуваного розчину у грамах;

P - вміст основної речовини в фосфатидилхоліні, використаного для приготування розчину порівняння, у відсотках;

$\rho$ - густина препарату.

Валідацію методик кількісного визначення вмісту фосфатидилхоліну, лізофосфатидилхоліну та бензилового спирту проводили згідно 3 рекомендаціями ICH за критеріями: специфічність, робасність, лінійність, точність і правильність, внутрішньолабораторна точність.

Для доказу специфічності було виготовлено плацебо препарату без вмісту фосфатидилхолі- ну. Для визначення критеріїв прийнятності на хроматограмі розчину плацебо повинні бути відсутніми піки, що збігаються за часом утримування піку фосфатидилхоліну на хроматограмі розчину порівняння. У разі присутності таких піків їх площа має бути незначущою порівняно з максимально припустимою невизначеністю результатів аналізу:

$\Delta_{A s} \bullet 0.32=0.512 \%$, тобто їх площа не має перевищувати 0,512 \% від середньої площі піків фосфатидилхоліну на хроматограмах розчинів порівняння.

Розчин плацебо піддавали стресовому впливу: УФ випромінюванню, високій температурі та окисленню.

На хроматограмах розчинів плацебо, що були піддані стресовому впливу, на місці піку фосфатидилхоліну були відсутніми піки, площа яких перевищує 0,512 \% від середньої площі піку фосфатидилхоліну на хроматограмах розчинів порівняння.

На рисунках 1 та 2 показано приклади хроматограм плацебо та розчину стандартного зразка фосфатидилхоліну.

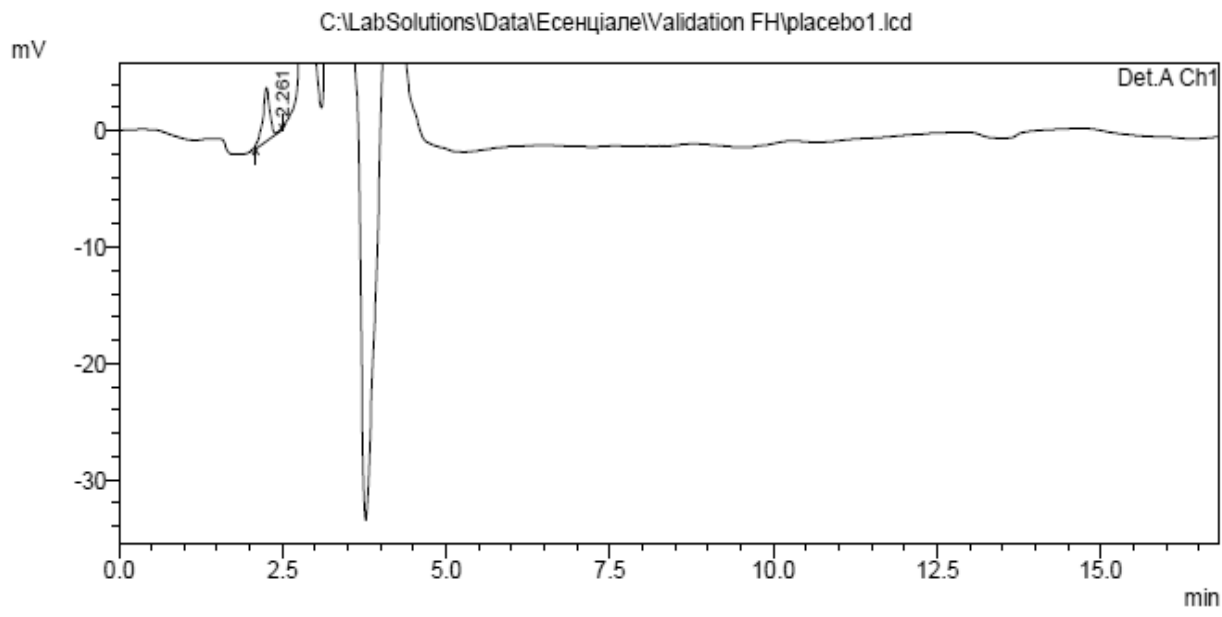

Рис. 1. Хроматограма розчину плацебо.

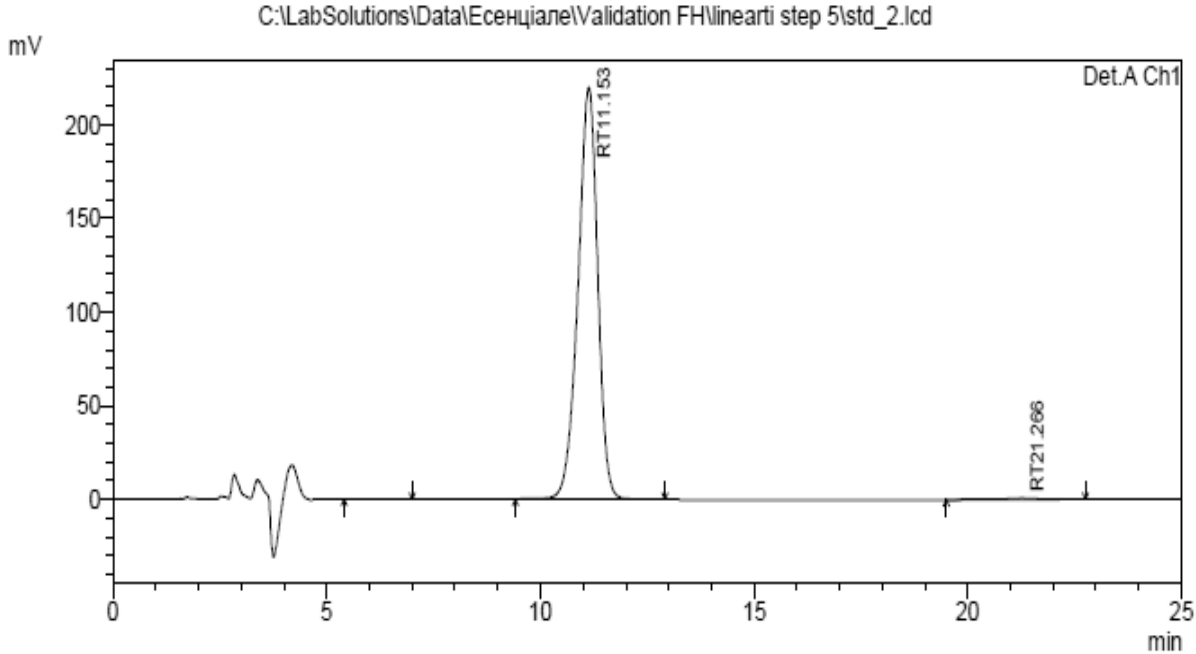

Рис. 2. Хроматограма розчину стандартного зразка фосфатидилхоліну.

ISSN 2312-0967. Фармацевтичний часопис. 2015. № 1 
Для доведення робасності температуру випробовувальної колонки змінювали в межах $(40,0 \pm 5,0){ }^{\circ} \mathrm{C}$; відповідно до рекомендацій Європейської фармакопеї, концентрацію гексану змінювали в межах \pm 2 \%. План проведення експерименту наведено у таблиці 1.

Таблиця 1. Програма вивчення робасності методики кількісного визначення

\begin{tabular}{|c|c|c|}
\hline № & Гексан & Температура \\
\hline 1 & + & + \\
\hline 2 & + & - \\
\hline 3 & - & + \\
\hline 4 & - & - \\
\hline
\end{tabular}

Різниця між значенням введено/знайдено вмісту фосфатидилхоліну для модельних розчинів відрізнялась від 100 \% не більше ніж на 2,26\%.

Лінійність вивчали на 9 модельних розчинах із концентрацією від 80 до 120 \% від номінального значення. Параметри лінійності наведено в таблиці 2.

Параметри точності та правильності наведено в таблиці 3.

Для визначення критеріїв прийнятності внутрішньолабораторної точності різниця між знайденим вмістом розчинів препарату, які аналізують в різні дні $\left(\Delta_{\text {AC }}\right)$, не повинна відрізнятися більш, ніж на $\Delta_{\text {As }} \cdot \sqrt{2}$, де $\Delta_{\text {As }}-$ максимально припустима невизначеність результатів аналізу, тобто

$$
\Delta_{A C} \leq \Delta_{A s} \cdot \sqrt{2}=2.26 \%
$$

Результати аналізу вважали достовірними, якщо були виконані вимоги до придатності хроматографічної системи.
При оцінці результатів різниця між середнім значенням результатів аналізу на хроматограмах випробовуваного розчину препарату, який аналізують в різні дні $\left(\Delta_{\text {AC }}\right)$, не відрізнялася більш ніж на 2,26\%.

Двома різними аналітиками в різні дні було проаналізовано 6 модельних розчинив 3 номінальною концентрацією фосфатидилхоліну. Розраховано концентрацію для кожного розчину ваговим методом, знайдено концентрацію відносно піку стандарту фосфатидилхоліну, розраховано стандартне відхилення відносної концентрації.

За допомогою вищенаведених даних нами було підтверджено, що вимоги внутрішньолабораторної точності витримуються.

Вміст супровідних домішок контролювали за методикою «кількісне визначення фосфатидилхоліну». Головною домішкою деградації фосфатидилхоліну $є$ лізофосфатидилхолін. Для доказу специфічності було приготовано та проаналізовано випробовуваний розчин препарату Лесфаль с.10810 та плацебо препарату. Хроматограми вказаних розчинів наведено на рисунку 3.

Як видно з представлених хроматограм, пік фосфатидилхоліну (вихід на 11,18 хв) добре розділяється, будь-які піки на хроматограмі розчину плацебо в місці виходу піків фосфатидилхоліну та лізофосфатидилхоліну відсутні. Отже, специфічність методики доведено.

Для визначення межі виявлення та межі кількісного визначення було приготовлено розчини стандартного зразку лізофосфатидилхоліну: 80 \% від 4 мг/мл (концентрація при випуску), 120 \% від 6,62 мг/мл (концентрація під час застосування) та $100 \%$ 5,31 мг/мл (середнє значення) (табл. 4).

Таблиця 2. Параметри лінійності методики кількісного визначення

\begin{tabular}{|c|c|c|c|c|}
\hline Параметри & Значення & Вимога 1 & Вимога 2 & Висновок \\
\hline $\mathrm{b}$ & 0,98647327 & & & \\
\hline $\mathrm{Sb}$ & 0,024332006 & & & \\
\hline $\mathrm{a}$ & $1,7822328 \mid$ & $<=|4,5250169|$ & $<=|4,6143567|$ & витримуються за першим критерієм \\
\hline $\mathrm{Sa}$ & 2,4334589 & & & \\
\hline $\mathrm{RSD}_{0}$ & 1,1709119 & & & \\
\hline $\mathrm{RSD}_{0} / \mathrm{b}$ & $1,1869677 \mid$ & $<=|1,7208927|$ & & витримуються \\
\hline $\mathrm{RSD}_{\mathrm{y}}$ & 16,228022 & & & \\
\hline $\mathrm{r}$ & $|0,99739352|$ & $>|0,99436138|$ & & витримуються \\
\hline
\end{tabular}

Таблиця 3. Параметри точності та правильності методики кількісного визначення

\begin{tabular}{|l|l|l|l|l|l|}
\hline & Параметри & Значення & Вимога 1 & Вимога 2 & \multicolumn{1}{|c|}{ Висновок } \\
\hline Точність & $\Delta_{\mathrm{d}}$ & 2,1146052 & $<=3,2$ & & витримуються \\
\hline Правильність & $\left|\mathrm{d}_{\mathrm{cp}}-100\right|$ & $|0,33309663|$ & $<=0,66869689$ & $<=1,0112$ & $\begin{array}{l}\text { витримуються за першим } \\
\text { критерієм }\end{array}$ \\
\hline
\end{tabular}

ISSN 2312-0967. Pharmaceutical review. 2015. № 1 
Аналіз лікарських препаратів

Analysis of drugs

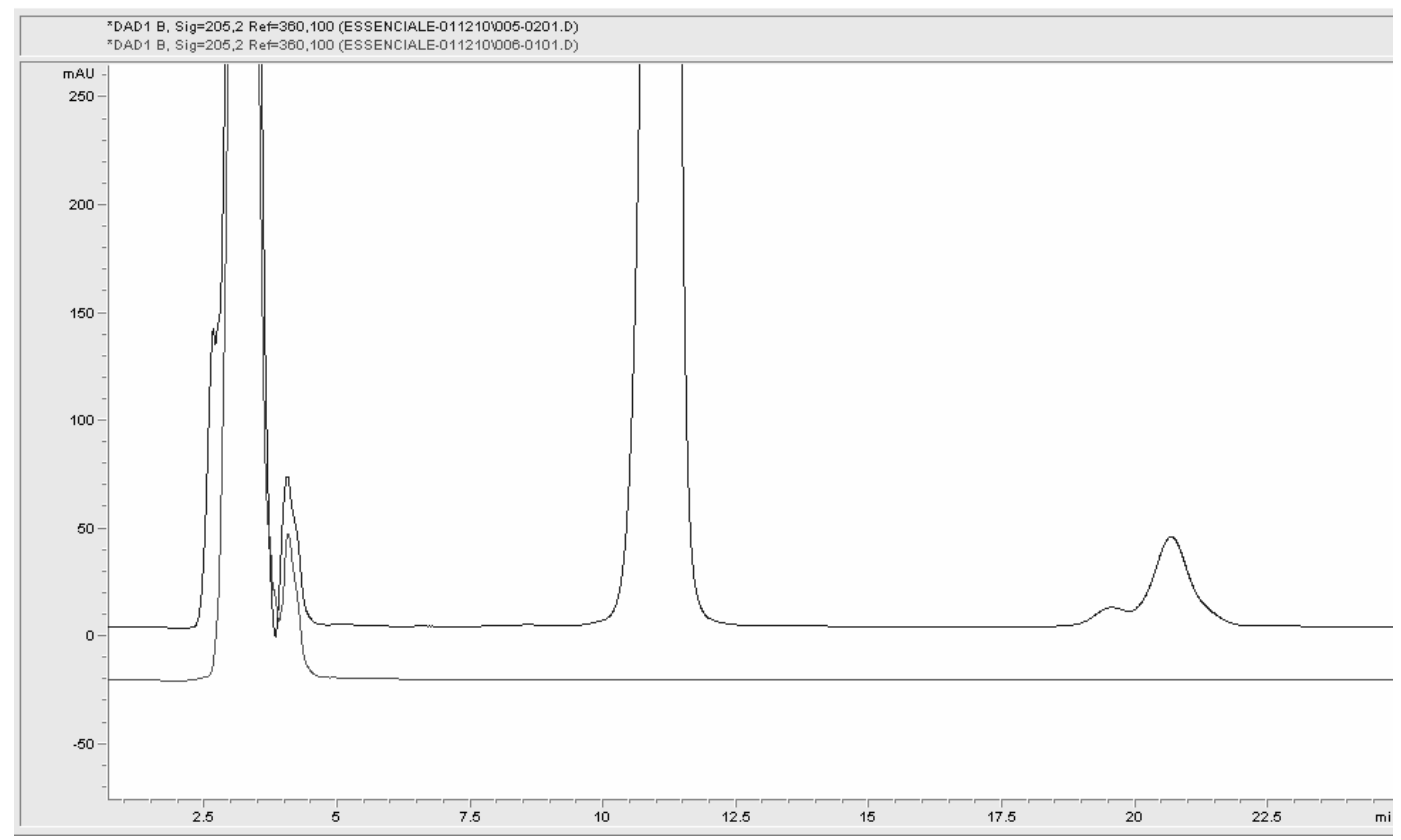

Рис. 3. Хроматограми розчину Лесфаль (1 - синій) та розчину плацебо (2 - червоний).

Таблиця 4. Концентрації розчинів для калібрувальної прямої

\begin{tabular}{|c|l|c|}
\hline № & \multicolumn{1}{|c|}{ Концентрація, вмісту лізофосфатидилхоліну } & Концентрація, мг/мл \\
\hline 1 & $80 \%$ від 4 мг/мл & 0,064 \\
\hline 2 & $100 \%$ 5,31 мг/мл & 0,106 \\
\hline 3 & $120 \%$ від 6,62 мг/мл & 0,158 \\
\hline
\end{tabular}

Результати аналізу наведено в таблиці 5 та на рисунку 4.

За даними рівняння регресії, що описує залежність площі піку від концентрації домішки лізофосфатидилхоліну, розраховано межу виявлення (MB) та межу кількісного визначення (MKB) у міліграмах в одному мл.

$$
\begin{aligned}
& M B=\frac{3.3 \times 75.34023}{21286.08255}=0.01167 \\
& M K B=\frac{10.0 \times 75.34023}{21286.08255}=0.03534
\end{aligned}
$$

Таблиця 5. Таблиця отриманих значень для побудови калібрувальної прямої

\begin{tabular}{|l|c|c|c|}
\hline Концентрація домішки, мг/мл & 0,064 & 0,106 & 0,158 \\
\hline Знайдена площа & 1224 & 2058,3 & 3234,4 \\
\cline { 2 - 4 } & 1256,3 & 2057,9 & 3196,8 \\
\hline Середня площа & 1240,15 & 2058,1 & 3215,6 \\
\hline СВ & 22,83955 & 0,282843 & 26,58721 \\
\hline ВСВ & 1,841676 & 0,013743 & 0,82682 \\
\hline
\end{tabular}

Висновки. 1. Проведено дослідження 3 розробки методик кількісного визначення фосфатидилхоліну та лізофосфатидилхоліну в препараті Лесфаль розчин для ін'єкцій. Запропонований аналітичний метод визначення вмісту фосфатидилхоліну специфіч- ний, лінійний, точний і правильний в діапазоні концентрацій діючої речовини 76$126 \%$.

2. Межа виявлення лізофосфатидилхоліну складає 0,01167 мг/мл та межа кількісного визначення складає 0,03534 мг/мл.

ISSN 2312-0967. Фармацевтичний часопис. 2015. № 1 


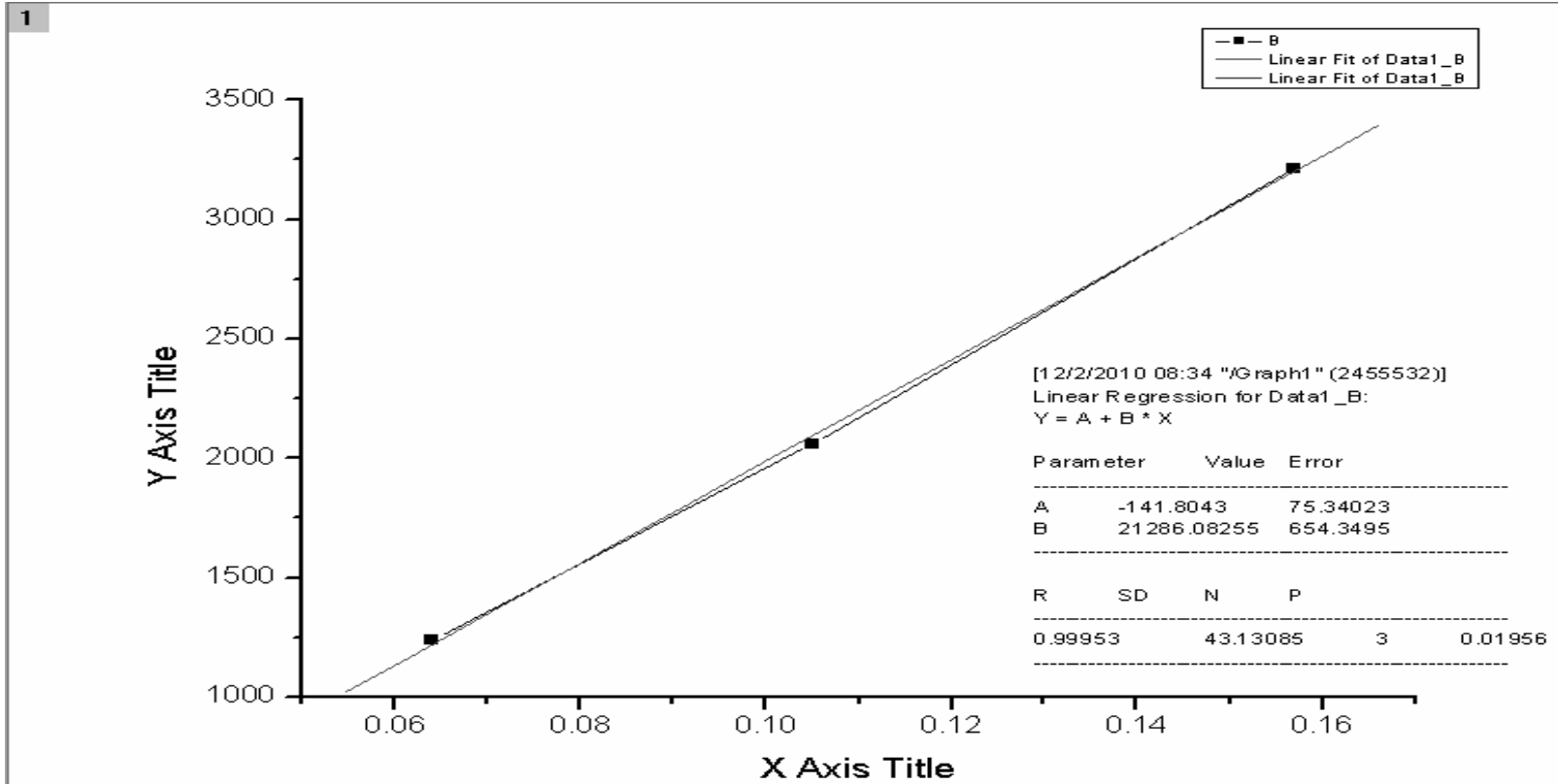

Рис. 4. Калібрувальна пряма для визначення межі виявлення та межі кількісного визначення лізофосфатидилхоліну.

\section{Література}

1. Вороніна А. К. Гепатопротекторна ефективність препарату Лесфаль за експериментального гепатиту в щурів / А. К. Вороніна, Г. І. Борщевський // Фармакологія та лікарська токсикологія. - 2013. - № 2 (33). С. 37-41.

2. Державна фармакопея України / Держ. п-во «Науково - експертний фармакопейний центр». - 1-е вид.

- Х. : РІРЕГ, 2001 - 536 c.

3. Патент № 97742, Україна А 61К 9/00 Ін'єкційний препарат на основі фосфатидилхоліну та спосіб його одержання / Жебровська Ф. І., Борщевський Г. І., Борщевська М. І., Костюк Г. В., № а 201013341; заявл. 10.11.2010; опубл. 12.03.2012.
4. Фактори, які впливають на стабільність препарату Лесфаль / [Борщевський Г. І., Комаров І. В., Кулініч А. В. та ін.] // Управління, економіка та забезпечення якості в фармації. - 2013. - № 6 (32). - С. 10-14.

5. European Pharmacopeia. $-7^{\text {th }}$ ed. - Strasbourg: Counsil of Europe, 2012. - 4504 p.

6. Mozafari M. R. Nanoliposomes: From Fundamentals to Recent Developments / M. R. Mozafari, S. M. Mortazavi // Trafford Publishing Ltd, Oxford, UK, 2005.

7. Sterically stabilized liposomes bearing anti-HLA-DR antibodies for targeting the primary cellular reservoirs of HIV-1. / J. Bestman-Smith, P. Gourde, A Desormeaux. [et al.]//Biochim. Biophys. Acta. - 2000. - Vol. 1468 (1-2). - P. 161-174.

\title{
РАЗРАБОТКА МЕТОДИК КОНТРОЛЯ КАЧЕСТВА ПРЕПАРАТА ЛЕСФАЛЬ РАСТВОР ДЛЯ ИНЪЕКЦИЙ
}

\author{
Г. И. Борщевский, Т. Г. Ярных, В. А. Коноваленко, В. Л. Гавриленко \\ 1 ПАТ «Фармак», Киев \\ ${ }^{2}$ Национальный фармацевтический университет, Харьков
}

Резюме: разработаны методики контроля качества липосомального инъекционного раствора Лесфаль. Предложен аналитический метод определения содержания фосфатидилхолина, специфичный, линейный, точный и правильный в диапазоне концентраций действующего вещества 76-126 \%. Предел обнаружения лизофосфатидилхолина составляет 0,01167 мг/мл, предел количественного определения составляет 0,03534 мг/мл.

Ключевые слова: инъекционный раствор, разработка, методики контроля качества.

ISSN 2312-0967. Pharmaceutical review. 2015. № 1 
Аналіз лікарських препаратів

Analysis of drugs

\section{DEVELOPMENT OF QUALITY CONTROL METHODIC OF THE MEDICINE LESFAL SOLUTION FOR INJECTIONS}

\section{G. I. Borshevskyi, T. G. Yarnykh, V. A. Konovalenko, V. L. Gavrylenko}

"JSC "Farmak", Kyiv

${ }^{2}$ National Pharmaceutical University, Kharkiv

Summary: the methodic of quality control of liposomal solution for injections Lesfal were developed. An analytical method for determination of phosphatidylcholine was proposed\$ it is specific, linear, accurate and correct in the active ingredient concentration range of $76-126 \%$. The detection limit of lysophosphatidylcholine is $0.01167 \mathrm{mg} / \mathrm{ml}$, the limit of quantification is $0.03534 \mathrm{mg} / \mathrm{ml}$.

Key words: solution for injections, development, quality control methodic. 